\title{
A magyar határőrizet változásai 1958-1990
}

A Magyar Népköztársaság államhatárának őrzését 1958-1990 között a belügyi tárca alárendeltségében tevékenykedő Határőrség végezte, mely egyben a fegyveres erők részét is alkotta. Alapfeladatát Magyarország államhatárának őrzése, a jogellenes határátlépések megakadályozása, a határforgalom ellenőrzése és a határrend fenntartása alkotta. Ezek az alapfeladatok ebben az időszakban lényegében nem változtak. A feladatok tartalma, fontosságának megítélése, végrehajtásának módja viszont — a nemzetközi és belpolitikai helyzethez igazodva, a hazánkban végbemenő társadalmi átalakulással összhangban - módosult. Ez szükségessé tette a határőrség erőinek átcsoportosítását, a belső tartalékok folyamatos feltárását és hasznosítását.

A határőrség tevékenységét alapvetően politikai döntések, a Magyar Szocialista Munkáspárt Politikai Bizottságának határozatai formálták. Az 1956. évi magyar forradalom és szabadságharc leverését követően hazánkban kialakult gazdasági, politikai, ideológiai zürzavar a határőrizetben is éreztette hatását.

Az 1950-es évek végére, az 1960-as évekre Magyarország külső és belső helyzete stabilizálódott. A gazdaság fellendülöben volt, amely hatást gyakorolt a határörizet, a határforgalom ellenőrzését elösegítő intézkedések tartalmára is.

A BM Határőrség munkáját a Magyar Szocialista Munkáspárt kongresszusainak és a Politikai Bizottság határozatainak megfelelően, valamint belügyminiszteri parancsok alapján végezte.

Az 1960-as évektől a magyar határőrség a növekvő határforgalom ellenőrzési teendőket a határörizeti, a határrendi szakfeladatokat javuló hatásfokkal, eredményesen hajtotta végre.

Az 1960-as években kezdődött idegenforgalmi nyitás következtében az 1980-as évekre az alapfeladatok végrehajtásában eltolódás történt a határforgalom ellenőrzés javára.

Az 1980-as évek végére a Magyar Népköztársaságban — és Közép-Európában — végbement társadalmi, politikai folyamatok, a bekövetkezett nemzetközi változások gyökeresen hatottak a határőrség feladatrendszerére, tevékenységére, müködésének körülményeire és feltételeire.

A határforgalom, a határátkelőhelyeken átlépő személy és jármüforgalom évek óta folyamatosan, dinamikusan, évente mintegy 20-40 \%-kal nőtt. Eszel egyidőben fokozódott az igény a gyorsabb, kulturáltabb, de megfelelően biztonságos és színvonalas forgalomellenőrzés iránt.

Az évtized végére a határhelyzet jelentős mértékben változott. Megsokszorozódott a tiltott határátlépési kísérletek száma. Nemzetközi ember- és árucsempész szervezetek jöttek létre. Kialakultak a hazai bünözés határokon túl nyúló kapcsolatai. Nőtt a nemzetközi kábítószer-kereskedelem megjelenésének, kiterjedésének a veszélye.

A BM Határőrség és a határőrizet történetében az 1980-as évtizeddel egy korszak zárult le. A régi szervezeti forma, s tevékenység már nem felelt meg az új elvárásoknak, azon változtatni kellett.

\section{A határőrzési feladatok}

Az 1950-es évek végére az 1960-as évek elejére kialakultak a tiltott határátlépést megkísérlők és elkövetők mozgásában az országos föirányok. A tiltott határsértést elkövetni szándékozók fő irányát az osztrák határ képezte.

Jugoszlávia - nem csatlakozott egyértelmüen, s minden szempontból a többi szocialista országhoz — a határsértők zömét nem is adták vissza, azok tovább mehettek Olaszországba, vagy Ausztriába, ezért a nyugatra irányuló határsértők másik fö irányává vált.

Csehszlovákia, Szovjetunió, Románia irányában ezekben az években a határsértések általában árucsempészetben, rokoni látogatásban nyilvánultak meg.

A határőrizet végrehajtásában, az erők, eszközök mennyiségi, minőségi elosztásában nagyarányú eltolódások alakultak ki a „nyugati”, „,éli” és „,északi-keleti” határőrizetről beszéltek. A nyugati határőrizet megkövetelte, hogy az osztrák határ mentén müszaki zárat, aknamezőt, nyomsávot, 3-4 kmként magasfigyelőt létesítsenek, a jugoszláv déli irányban csak nyomsáv és magasfigyelő volt, a baráti viszonylatban pedig a határ nem volt müszakilag megerősítve. ${ }^{1}$

A határőrizeti feladatokban legtöbbször a különbségek is e három iránynak megfelelöen jelentkeztek és az eredményesség értékelésekor is ennek megfelelően történtek az összegzések, lehetővé téve a határ örizetében bizonyos szakosításokat, új módszerek bevezetését. ${ }^{2}$

A csehszlovák, szovjet és román határon jó határőrizeti együttmüködés jött létre a szomszédos országok határőrizeti szervezeteivel, mely kölcsönösen kiemelkedő határőrizeti eredményekben realizálódott, a határon viszonylag nagy határszakaszt őrző kis létszámú örsök látták el feladatukat. Ezekben a viszonylatokban a határőrzést elöbb 2 fős, majd 1968-tól 1 fós járőrökkel hajtották végre. A nagy távolságok miatt vízen hajóval és motorcsónakkal, szárazföldön kerékpárral portyáztak. 
A baráti viszonylatú határszakaszon a jó együttmüködésnek, a határsértők csekély aktivitásának köszönhetően már az 1960-as években kétszer is felvetődött a hivatásos állományúakkal történő határőrizetre való áttérés gondolata. Kísérleti jelleggel 1961. áprilisa és 1962. szeptembere között 6 örsön felállitásra is került a „hivatásos határőrizet”. Az elvárások igazolódtak, az örs müködési területét a járőrök között szektorokra osztották, annak sérthetetlenségéért a járőrök felelösséget éreztek, ezért kiépítették kapcsolataikat a helyi lakosság körében. Ezen rövid kísérleti időszak alatt megfelelő költségmegtakarítás mutatkozott. Az áttérés folytatását azonban felfüggesztették, a kezdeti nagyfokú beruházási igény miatt — lakások kialakítása —, amire nem volt pénzügyi keret.

Gyenge volt a jelentkezett tiszthelyettesi állomány általános müveltsége (5-6 osztály), mely nem felelt meg az elvárásoknak. A meglévő állomány körében nagy volt a lemorzsolódás, $\mathrm{s}$ annak pótlása is nagy gondot okozott.

A hetvenes évek végétöl a szocialista országokban bekövetkezett változások kapcsán különösen megemelkedett a keleti és északi viszonylatban a határsértők, menekültek befelé irányuló mozgása, amely már tömeges méreteket öltött. Döntö többségük azonban nem hazánkban akart letelepedni, hanem az ország területét átszelve nyugaton illetve délen próbált meg továbbszökni Nyugat-Európába. Az 1980-as években ezért a baráti országok határain, de főleg a román határon fokozatosan megerősítették a határőrizet erőit, eszközeit, hogy megakadályozzák azon személyek bejutását az országba, akik a „menekült” néven jönnek hazánkba, de a nyugatra történő továbbszökésük a fó céljuk.

Nyugati és déli irányban a határsértők aktivitása, létszáma 1958-1990 között kiemelkedően magas volt. Voltak évek, amikor az egyik vagy másik irány aktivitása nőtt illetve csökkent, esetleg az egyik irányban foganatosított intézkedések kihatással voltak a másik irányban jelentkező határsértést megkísérlők számára.

Az 1960-as évekre azonban a jugoszláv viszonylatú határszakaszon — az államközi kapcsolatok rendezésével összhangban, az egyezmények alapján — rendezett határmenti viszonyok alakultak ki. Ez lehetővé tette, hogy a déli határszakaszon - a nyugati viszonylat $20 \mathrm{~km}$-es határövezetével szemben — csak 5 km-es határövezetet tartsanak fenn, majd 1965-re teljesen megszüntessék. Az itt lévő határôrizet erőinek és eszközeinek zömét pedig a nyugati határszakaszra összpontosították. ${ }^{3}$

Gondot okozott a nyugati és déli határszakasz mélységének ellenőrzése, az ország belsejéből a nyugati és déli irányba tiltott határátlépést elkövetni szándékozók elfogása. Ezt a feladatot elsősorban a vonatellenőrző századok a határ felé közlekedő személyszállító vonatok menet közbeni ellenőrzésével, valamint a mélységben állomásozó tartalék őrsök, kiszolgáló alegységek okmányellenőrző járöreivel a határközeli települések, határ felöli kijáratainak nyílt, majd rejtett ellenőrzésével hajtották végre. A vonatok ellenőrzését korábban sorozott állomány, 1964-től pedig hivatásos és sorállomány rejtetten — polgári ruhában — végezte. A tevékenység eredményes volt, mert évente ily módon több száz föt fogtak el, ezzel is tehermentesítve a nyugati és déli határszakaszt őrzö örsöket. ${ }^{4}$

A foganatosított intézkedések ellenére a nyugati irányba tiltott határátlépést elkövetni szándékozók még mindig magas számban érték el az őrsök müködési területét, s a járörök éberségét kijátszva próbáltak osztrák területre jutni. $^{5}$

A nyugati határszakasz örzésénél a határ szinte résmentes lezárása volt a cél. A határ örzését álló (figyelő), álló-mozgó (szakasz) és mozgó (portyázó, nyomsávellenőrző) járőrök végezték. A nyugati őrsök nagyobb létszámmal és kisebb határszakasszal $(5-10 \mathrm{~km})$ rendelkeztek, figyelembe véve a határsértők mozgásának valószínủ irányait és a terepviszonyokat. ${ }^{6}$

A határ őrzésében egyre nagyobb helyet kaptak a jelzőkészülékek, melyek több típusa volt használatban. 1963 után különösen elterjedt a H-64 M. jelzőkészülék alkalmazása, mely lényegében a határsértők valószínű mozgási irányaira merőlegesen térdmagasságban kihúzott vékony drótszál volt. A drótszálak vége egy-egy kisrakéta kilövőjéhez kapcsolódott. A drótszál kihúzása esetén a különböző színủ kisrakéták fellövése jelezte a határőr járőrnek az esetleges határsértő mozgását. A rakéták önköltségi árának emelkedése és az egyéb mozgásból (állatok stb.) adódó feleslegesen sok rakéta felhasználása miatt a készülékek fenntartása egyre költségesebbé vált. A nyolcvanas évektől keresték kiváltásának lehetőségét és a bekövetkezett sok baleset miatt egy sor szigorító intézkedést vezettek be használatára. ${ }^{7}$

A fegyverhasználat is szigorúbb volt a nyugati határszakaszon. A határsértést elkövetni szándékozó személy megállásra történő felszólítása és figyelmeztető lövés leadása után a járőrnek tüzelnie kellett, amennyiben felszólított személy nem tett eleget a figyelmeztetésnek. ${ }^{8}$

Az osztrák viszonylat határőrizetének előtérbe kerülése azt is eredményezte, hogy 1964 végére a BM Határőrség személyi állományának 42,3\%-át, technikájának pedig 40,6 \%-át a nyugati határon alkalmazták. ${ }^{9}$ 
A határsértők mozgása 1964-1965-ben tovább emelkedett, az 1957-ben telepített müszaki zár viszont elavult.

Az aknazár — bizonyos erkölcsi visszatartó ereje mellett — erre az időre már csekély garanciát nyújtott a müszaki záron való áthaladás megakadályozására. Szükségszerüvé vált az aknamező felszedése, felváltása más eszközzel.

A Magyar Szocialista Munkáspárt Politikai Bizottsága 1965. V. 11-én határozatot hozott szovjet mintára készülő, 50 km-es jelzőrendszer kísérleti megépítésére és az aknazár egyidejü felszedésére. ${ }^{10}$

A pozitív tapasztalatok hatására a Magyar Szocialista Munkáspárt Politikai Bizottsága 1966. VI. 21-ei ülésén elfogadta, hogy 1969-ig a BM Határőrség az egész nyugati határszakaszon folytassa az építést és az aknazár felszedését. ${ }^{11}$

Az elektromos jelzőrendszer építése 1969. X. 30-án fejeződött be, az aknamező felszámolása pedig 1971. IX. 2-án összesen 246 km hosszban készült, el a jelzőrendszer és 48 örsöt érintett. Az elektromos jelzőrendszer jelentős változást hozott a határőrizetben. A határőrizeti szolgálati feladatok ellátásának feltételei a nyugati határszakaszon megváltoztak. A jelzőrendszer kiépítése maga után vonta a mélységi határőrizeti szolgálati módszerek és az őrsök szolgálati rendszerének fejlesztését is. Ehhez növelni kellett a - lóállomány csökkentése mellett — gépjármüvek mennyiségét. Az őrsök gépkocsikat kaptak ehhez a földutakat használhatóvá kellett tenni. A távbeszélő hálózatot jelentősen kibővítették. Az őrsök személyi állományába kiképzett jelző-technikus katonákat rendszeresítettek az elektromos jelzőrendszer mindennapos kiszolgálására. A járőrkutyák kiképzését a jelzőrendszer működéséhez igazították. Az őrsök számára előzetes intézkedési terveket dolgoztak ki a jelzőrendszer különböző irányokba történő müködése esetére. A hivatásos és sorállományt a feladatok begyakoroltatásával felkészíteni az új tevékenyégre.

A polgári lakosságot érzékenyen érintette a jelzörendszer kiépítése, hiszen a lezárt területre (határsáv) új belépési engedélyek kellettek, a belügyminiszter utasítása alapján az SZ-100 jelzőrendszer kiépítésével az 50 és 500 méteres határsáv megszünt, a továbbiakban a határsávot a jelzőrendszer és a határvonal közötti területsáv képezte és ennek mélysége többszöröse volt a megszüntetett határsávokénak. Belépéshez a határövezeti engedélyen kívül a határőrség illetékes szervezetének külön engedélyére is szükséges volt. A belépést megfelelő kapuk segítségével biztosították. A kapukhoz okmányellenörző járöröket vezényeltek. ${ }^{12}$

A jelzőrendszer felépítését, a javuló határörizet, a lakosság aktív segítségét alapul véve a Magyar Forradalmi Munkás-Paraszt Kormány a nyugati határövezetet 1969. V. 1-ével megszüntette. ${ }^{13}$

Az elektromos jelzőrendszer müködésének kivizsgálására az őrsökön naponta a bent lévő személyi állományból 8-16 fős zárócsoportokat és 4-6 fös üldözőcsoportokat szerveztek. Az üldözőcsoportba jelzö-technikust és kutyavezetőt kutyával osztottak be, míg parancsnokául rendszerint hivatásos állományút jelöltek ki.

Az elektromos jelzőrendszer müködése eseten feladatukat a következőképpen hajtották végre, mindkét csoport riadózott, a zárócsoportot gépkocsin a kijelölt zárási szakaszra szállították, ott szétbontakozva lezárta az adott határszakaszt. Az üldözőcsoport gépkocsival a jelzés helyére ment, ott a nyomsávot és a jelzőkerítést átvizsgálva megállapította a jelzés okát. Ha a riasztást határsértő okozta, a nyomok alapján kutya segítségével megkezdte a határsértő üldözését. A jelző-technikus katona a jelzőrendszert visszaállította eredeti helyzetébe és biztosította a hátramaradt nyomokat.

A jelzőrendszer megépítése és a hozzá igazított határörizet ellátása mind az őrsökre, mind a kerület-parancsnokságokra jelentős feladatokat rótt. A kerület-parancsnokságoknak is az új határőrizeti módhoz szükséges tervek, okmányok kidolgozását, az új feladatokra az állomány felkészítését a legjobb módszerek kiválasztását kellett biztosítani.

Az 1970-es évektől az elektromos jelzőrendszer jelentősen segítette a határőrség munkáját. A H63 M. jelzőkészüléket és kutyákat növekvő mértékben alkalmazták SZ-100 elektromos jelzőrendszer kiegészítésére. A határsértők mozgásában az elektromos jelzőrendszer, az első időszakban déli irányba történő terelő hatást is kiváltott. Az erők, eszközök változatosabb és eredményesebb alkalmazásával, a határőrizeti rendszer kiigazításával törekedtek a feladatok megoldására a déli határszakaszon is. A határsértők aktivitása fokozatosan csökkent, nyugaton és délen eredményesen alkalmazták a mozgó-, kihelyezett járőrcsoportokat, a figyelö-jelzőrendszert, mégis százalékos arányát nézve sok határsértőnek sikerült az első lépcsőben müködő őrsök területére lejutni. Ezért egyre nagyobb hangsúlyt kapott a mélységi határőrizet erősítése, szilárdítása. ${ }^{14}$

Az 1980-as években a határ megsértésére törekvők új eszközhöz folyamodtak. Rövid időn belül megsokszorozódott azoknak a száma, akik légi utón próbáltak kiszökni az ország területéről. Az esetek zömében Ausztriából kis sportgép berepült és a leszállásra alkalmas, határhoz közeli területen fel- 
vette fedélzetére a kiszökni szándékozó személyeket és — mielőtt bármit is ténykedhetett volna a határőrség — visszarepült Ausztriába.

A légi határ őrzésének biztosítása, légtérsértések és a légi utón történő kiszöktetések megakadályozása érdekében a BM Határőrség a Magyar Néphadsereg Repülőfőnökséggével együttmüködve 1981. IX. 5-30-áig a későbbiekben minden év április 15-étől szeptember 30-áig a nyugati kerületek hadműveleti alárendeltségében honvéd helikopteres őrjáratozást hajtottak végre az államhatár mentén. 1987-től 1989. IX. 1-ig — amikortól a helikopterek további alkalmazása a kialakult politikai helyzetben már nem volt célszerü — csak a győri, szombathelyi és zalaegerszegi kerületeknél alkalmazták a készültségi helikoptereket. ${ }^{15}$

A Magyar Szocialista Munkáspárt Politikai Bizottsága 1986. IX. 9-én megtárgyalta a Központi Bizottságnak a BM munkájáról szóló 1969. XI. 28-ai határozata teljesítésének helyzetét, s úgy értékelték, hogy a határőrizet az elmúlt években kiegyensúlyozottan, a társadalmi követelményekkel lépést tartva fejlődött. Már ebben az évben a bekövetkező politikai változások előszeleként jelentkeztek olyan kérdések, amelyeket a BM Határőrség vezetőinek meg kellett vizsgálni, arra intézkedéseket kellett foganatosítani. ${ }^{16}$

Az elektromos jelzőrendszer müszaki állapotának elöregedése miatt sok bírálat érte a határôrséget, mely megkérdőjelezte a rendszer szükségességét. A területi állami- és pártszervezetek, idegenforgalmi hivatalok a kérések tömegével léptek fel a rendszer megszüntetése, átépítése, elterelése miatt.

Megkezdődött a vezetést segítő korszerű technikai eszközök telepítése, a számítógépek határőrségi alkalmazásának bevezetése, kiemelt figyelmet fordítva a vezetői-irányító rendszerre.

A nyolcvanas évek végére jelentősen megnőtt a határsértést elkövetni szándékozók létszáma az osztrák, jugoszláv határon. A határsértést csoportosan és a határvonal teljes szakaszán kísérelték meg, felborítva a korábbi években kialakult „föirány okát”. Jellemző volt, hogy a határsértők mozgását meghatározó tényezők közül elsősorban a szomszédos országok társadalmi, politikai, gazdasági körülményei, velük fennálló kapcsolataink változásai domináltak. Ugrásszerủen megnőtt a romániai menekültek befele irányuló mozgása, egy részük tovább akart szökni nyugatra.

Az osztrák és jugoszláv határon több száz német állampolgár kísérelt meg nyugatra jutni.

A határőrség egész vezetői állományát érintő viták konzultációk során alakultak ki az ellenőrzés új rendjére, a szervezetfejlesztés fő irányaira a mélységi határőrizet átszervezésére, az egy fős járőrszolgálat kiszélesítésére, a munkastílus javítására kiadott parancsok, utasítások.

Megkezdődött a mélységi irányok operatív erőkkel történő ellenőrzésének megszervezése. Korlátozásra került a nyílt, katonai tevékenység, módosult az örsök, mélységi őrsök határórizeti rendszere.

Az alegységek erőivel való ésszerübb gazdálkodás érdekében nyugaton is általánossá vált az egy fös járőrök alkalmazása, szigorították a határőrség fegyverhasználatát. Csökkentették a járőrök, örsök szolgálati lőszer mennyiségét. Kiképzőbázisok személyi állományát is bevonták a határőrizetbe.

Mindezek az intézkedések kedvező irányba befolyásolták a határőrség fejlődésének irányát. ${ }^{17}$

Jelentős változást eredményeztek az 1989-1990-es évek. A határörség javaslatai alapján a minisztertanács 1989. V. 18-ai határozatában elrendelte az elektromos jelzőrendszer lebontását, a határsávi, határvízi korlátozások és a nyomsáv megszüntetését. Ebben az évben a győri kerület dunai határszakaszán beindult a hivatásos határőrizetre történő átállás előkészítése. ${ }^{18}$

Az Német Demokratikus Köztársaságban kialakuló átalakulási folyamat sajátosan jelentkező előzménye volt, hogy Német Demokratikus Köztársaság állampolgárai tömegesen hagyták el hazájukat, és Magyarországon keresztül nyugatra akartak szökni. A jelenség egybeesett az elektromos jelzörendszer és a korlátozások megszünésével, amelynek következtében a nyugati határszakaszunkon rendkívüli helyzet alakult ki. Az 1989. IX. 11-ei kormánydöntést követően — a keletnémet állampolgárokat a továbbiakban szabadon kiengedte a határőrség Ausztriába - Csehszlovákia részéről az Német Demokratikus Köztársaság állampolgárai legális utazásának korlátozása miatt augusztus, szeptember, október hónapban északi viszonylatban rendkívül sokan jöttek befele a ,zöldhatáron”. ${ }^{19}$

Ebben az két évben a nagy kiterjedésü razziák helyett kisebb létszámú, elsősorban az őrsök erőiből álló riadócsoportokat alkalmaztak. A csoportos tiltott határátlépést (vagy kísérletét) elkövetők arányának növekedése miatt visszatértek a két fős járőrök, esetenként a járőrcsoportok alkalmazására.

A dunai határszakaszon beindult hivatásos határörizet tapasztalatai pozitívak voltak, a határörizet kulturáltabbá, a beosztottak intézkedő-képesebbekké a gépkocsival történő járőrözés mozgékonyabbá vált. Megkezdődött a balassagyarmati és miskolci kerületek hivatásos határörizetre való átszervezése.

Az 1990-es év végére viszont bebizonyosodott, hogy a határőrség tevékenységét zavarja a törvényi szabályozás hiánya, a határőrizet átalakításának pedig elengedhetetlen feltétele a már előkészítés alatt álló határörizeti törvény hatálybalépése. 


\section{A határforgalom ellenőrzés}

A Magyar Köztársaság nemzetközi kapcsolataiban, a belpolitikában, az utazási feltételekben végbement változásokkal összhangban, a határforgalom az 1960-as évek közepétől dinamikusan növekedett és ellenőrzése 1990-re már a határőrség feladatrendszerén belül meghatározóvá vált. Ez idő alatt rohamosan gyarapodott a határon átléptetett személyek, jármüvek és szállítmányok száma. Az 1980-as évtized végére a világútlevél bevezetésének hatására kiugróan nőtt az osztrák határszakaszon a forgalom. (I.sz. melléklet)

Ezzel párhuzamosan a határőrség folyamatosan fejlesztette a határforgalom ellenőrzés rendszerét, növelte a személyi állomány felkészültségét, az ellenőrzés technikai bázisát.

Az 1980-as évtizedre bebizonyosodott, hogy az idegenforgalom az ezredfordulóra a világ vezető ágazata lesz, ezért szükséges az idegenforgalom és a határőrség tevékenysége közötti koordinálás, a határforgalom ellenőrzésének korszerüsítése.

A határforgalom növekedés feltételeinek megteremtéséhez tartozik az infrastrukturális fejlesztés is. 1959-ben a határforgalom ellenőrzésében összesen 23 forgalomellenőrzö-pont, 1963-ban 28 forgalomellenőrzö-pont, 1971-ben 33 forgalomellenőrzö-pont és 5 kishatárforgalmat lebonyolító határátkelőhely, 1980-ban 37 forgalomellenőrző-pont és 5 kishatárforgalmi határátkelőhely vett részt. 1990-ben pedig - a nagy politikai változások és a helyi lakosság igényeinek hatására — már több mint 50 forgalomellenőrző-ponton és kishatármenti forgalmat lebonyolító határátkelöhelyen történt az utasok ellenőrzése. A forgalomellenörzö-pontok számának növekedését a szomszédos országokkal való kapcsolatok szélesítése is lehetővé tette. Csehszlovák és román viszonylatú határátkelöhelyek közül többet már az 1960-as években közös határállomássá alakítottak át, mely közös elhelyezésben végzett önálló ellenörzést jelentett.

A növekedés nem csak számszerüségében mutatkozott meg, hanem szervezeti módosulásokban, létszámnövekedésben, az átkelőhelyek átépítésében is. A forgalomellenőrző-pontokat 1971-től a forgalom nagyságától függően I-IV. kategóriába sorolták, egyes határátkelőhelyeket pedig kiemelten kezeltek, esetleg magasabb egység szintre emeltek az 1980-as években.

Természetesen az infrastrukturális változások mellett az ellenőrzés módszerein is változtatni kellett.

Az ötvenes évek végén, a hatvanas évek elején a nyugati határon a forgalom ellenőrzésében szigorítások történtek a nyugati állampolgárokkal szemben. 1960-ban korlátozták az osztrák beutazók mozgását a magyar határállomásokon, az Amerikai Egyesült Államok állampolgárainak mozgását pedig az egész országban, mivel részükre zárt területté nyilvánítottak több megyét is.

Az 1962-es év enyhülésének térhódítása a határon is beutazási könnyítéseket eredményezett, mely jelentősen növelte a nyugati állampolgárok utazási kedvét és kezdetét vette az idegenforgalom növekedése.

A forgalom gyarapodását segítette elö, hogy Ausztriával egyezményben rögzítették az útlevél- és vámellenőrzés rendjét, könnyítették a Német Demokratikus Köztársaságba utazók számára az útlevél kiadását, aláírták a magyar-jugoszláv határforgalomról szóló egyezményt, mely a diplomata és szolgálati útlevelekre vízummentességet biztosított.

Az 1964-es év egyik kiemelkedő jelentőségü eseménye volt a vízumrendszer korszerüsítése. A követségeken a vízumkiadás idejét 24 órára csökkentették és 1964. X. 1-étől a Külföldieket Ellenőrzö Országos Központi Hatóság kirendeltségeket telepített tizenegy nagyobb közúti határátkelöhelyre, valamint Ferihegyre és Budapesten a Belgrád rakparti hajóállomásra.

Az utazás könnyítése már 1964-ben meghozta a kívánt eredményt. A személyforgalom az előző évhez képest 85 \%-kal emelkedett, a határátlépések száma megközelítette a 7 milliót. Az 1960-as évhez viszonyítva a forgalom a korábbiak háromszorosát tette ki.

A forgalom ilyen mérvủ növekedése kedvezőtlen hatásokat eredményezett, melyek kiküszöbölése, mind a munka végrehajtásában történő módszerbeli változásokat, mind pedig eszközbeli fejlesztéseket igényeltek. Ekkor került sor csehszlovák viszonylatban a csehszlovák és magyar állampolgárok esetében az egyoldalú ellenőrzés bevezetésére. Jelentősége ennek kiemelkedő volt, mert a II. világháború után Közép-Európában itt fordult először elő, hogy egy állam egy szomszédos, másik államot hatalmazott fel ilyen feladat ellátására.

A forgalomnövekedés és az úgynevezett állambiztonsági feladatok összhangba hozását szolgálta a jelentési rendszer korszerüsítése a forgalomellenőrző-pontokon. A határátkelöhelyek géptávíró összeköttetést kaptak, s megfelelő jelentő rendszer kidolgozása után a nyugati állampolgárok ki- és beléptetését, valamint a magyar állampolgárok nyugati utazásait, közvetlenül a Belügyminisztériumba jelentették géptávírón. Ezt a feladatot előbb sorkatonák, majd polgári alkalmazottak látták el, így fokozatosan megnőtt a polgári alkalmazottak száma a forgalomellenőrzö-pontokon.

Az 1970-es évek közepétől a forgalom ellenörzésében eredményesen került alkalmazásra az 
„IKVA” rendszer. Közúton, közvetlenül az autók mellé beállított ellenőrző fülkék használata elősegítette a forgalom ellenőrzés biztonságát, növelte a figyelőztetés megbízhatóságát és a konspirációt.

Az idegenforgalom az 1980-as évtizedre már olyan méreteket öltött, hogy a határátkelőhelyeken átlépő utasok ellenőrzése, manuális utón rendkívül hosszú időt vett igénybe.

1984-től a technikai fejlesztés fö hangsúlya a gépi adatfeldolgozás kiépítésére irányult. Először kísérleti jelleggel Hegyeshalomban, majd beválását követően Ferihegyen, Sopronban ezt követően pedig több forgalomellenőrző-ponton került bevezetésre a kisszámítógépes rendszer.

Az 1980-as évek második felében, hazánkban több olyan jelentős változás is bekövetkezett, mely megkérdőjelezte a teljes körü „totális” forgalomellenőrzés szükségességét, végrehajtásának lehetőségét. Az ellenőrzéssel szemben támasztott szakmai követelmények és az ehhez kapcsolódó módszerek az 1960-1970-es években kerültek bevezetésre. A feladatok azonban 15-20 év alatt a többszörösére növekedtek. A gyorsabb, kulturáltabb ellenörzésnek nem csak a személyi, technikai feltételei hiányoztak, a gyorsítás érdekében már politikai döntésre volt szükség. A BM Határörségen túl, különböző minisztériumoknak is lépniük kellett. ${ }^{20}$

A Magyar Szocialista Munkáspárt Politikai Bizottsága 1987 V. 19-én határozatot hozott a határforgalom ellenőrzésének gyorsítására. A határozatban foglaltak végrehajtására a belügyi tárca illetékes szervezetei utasításokat dolgoztak ki és elkészültek a határfigyelőztetések felfüggesztésével, az átléptetések gyorsításával kapcsolatos határőrségi intézkedések is. A határfigyelőztetési feladatok végrehajtásának meghatározott ideig történő felfüggesztését, már az 1987-es turista szezonban, nyári föidényben az osztrák-magyar viszonylatban alkalmazták. ${ }^{21}$

Az 1988-as évben a határforgalom dinamikus fejlődése tovább folytatódott és az elöző évekhez képest jelentős változásokat hozott. Megszünt a forgalom erőteljes ciklikussága, nem határolódott el a nyári nagy forgalmi időszak és egy héten belül az egyes nagy forgalmú napok.

Egy napon belül - a korábbitól eltérően — egybeesett a ki- és belépő csúcsidőszak. Erőteljesen növekedett a forgalom koncentrálódása a nyugati viszonylatra, ezen belül a nagy közúti forgalomellenőrzöpontokra. Egész évben intenzíven alkalmazták a határfigyelőztetés ellenőrzésének felfüggesztését.

Budapest-Bécs viszonylatban megszüntették a vonatok menet közbeni kutatását. Ujraszabályozták a fegyverhasználat, a fegyver-hordmód rendjét, a sorompók kezelését. Továbbra is gondot jelentett, hogy nem volt kialakult határforgalmi együttmüködés a túloldali szervezetekkel.

Ezekben az években az útlevélkezelést hozzávetőlegesen 90 \%-ban - eltéröen a környező országok gyakorlatától - sorállományú határőrök hajtották végre. A 12 hónapos sorkatonai szolgálatra való áttérés miatt 11 hétre rövidült kiképzési időszak alatt azonban nem lehetett megfelelöen felkészíteni a 18-21 éves idegen nyelvismerettel és gyakran érettségivel sem rendelkező fiatalokat. Szükségessé vált, hogy a sorállományú útlevélkezelőket fokozatosan hivatásos tiszthelyettesekkel váltsák fel.

Összességében az 1980-as évtized végére korszerübbé vált a határforgalom-ellenőrzés gyakorlata, megszünt a totális, többszörös ellenőrzési módszer, ugyanakkor az ellenőrzés biztonsága nem csökkent számottevően.

Az eltérő felfogás és érdekeltség miatt felszínre kerültek az együttmüködés gondjai. Az együttmüködés újraszervezése nem csak a határforgalom ellenőrzésében résztvevő szervezetek között, hanem nemzetközi téren is sürgetővé vált.

\section{A határrend fenntartása}

1958-1990 között a határrend fenntartásában és a nemzetközi kötelezettségek teljesítésében jelentős eredményeket ért el a BM Határőrség.

Az 1960-as évekre már — Ausztria kivételével — a határ rendjével és a határforgalommal kapcsolatos témákat nemzetközi egyezményekben szabályozták.

Határmegbízotti rendszert alakítottak ki — Ausztria kivételével — valamennyi szomszéd állammal, ami állandó és szoros kapcsolatot eredményezett ezen országok határőrizeti szervezeteivel.

Határainkon a szomszédos országokkal egyezményekben megkötött elvek alapján biztosították a határrend fenntartását, a határvonal és határjelek láthatóságát, karbantartását és felújítását.

A szerződésekből, egyezményekből adódó feladatokat a magyar fél törekedett betartani. A határrend sértések száma évente csökkenő tendenciájú volt, az esetek 3/4 részét a szomszédos országok területéről követték el. Az 1980-as évekre osztrák részröl nagyon megszaporodott a légtérsértések száma rövid idejü berepülések, átrepülések, s egyes esetekben kiszökni szándékozó határsértők légi utón történő kiszállítása. ${ }^{22} \mathrm{~A}$ határrendsértéseket a szomszédos államok szervezeteivel az egyezményekben foglaltak szerint rendezték. A határrendsértések eseteit a határőrizeti szabályzatok is rögzítették. 1982ben módosították a határrendsértések fajtáit. Az áttévedést, az állatátkóborlást és a vízijárművek átsodródását a továbbiakban nem tekintették határrendsértésnek. 
A nyugati és déli viszonylatban a határövezet törlése után a határsáv az 1980-as évek végéig fennmaradt.

A határsávval kapcsolatos rendelet betartása elősegítette a nyugati és déli viszonylat határőrizetének eredményességét. A határsávi, határvizi-közlekedési, határvizi-horgászati engedélyek kiadásának száma nőtt, az engedélyek fennállásának utolsó éveiben meghaladta az évi 50 000-et. Ez jelentős erőket kötött le, ezért a határőrség javaslata alapján, a kialakult új belpolitikai helyzetben a minisztertanács 1989. V. 18-ai határozatával megszüntette a határsávi, határvízi korlátozásokat. ${ }^{23}$

\section{A határkerületek irányító tevékenysége}

A határt őrző, a határforgalom ellenőrzését végrehajtó, valamint a szakfeladatokat ellátó alegységek irányítását, ellenőrzését és ellátását közvetlenül a határör kerület-parancsnokságok valósították meg. A feladatokat részben a korábbi időszakok módszerei alapján, illetve azokat továbbfejlesztve hajtották végre.

Az alapfeladatokat a kerületek parancsnokai határörizeti parancsokban határozták meg 1960-ig negyedévenként, utána félévenként, úgynevezett határőrizeti időszakonként őszi-téli, illetve tavaszinyári terminusra. A határőrizeti időszakokra történő áttérés tehát nem a naptári évhez igazodott, hanem az úgynevezett határörizeti és kiképzési évhez, mely októbertöl-szeptemberig tartott. Ezek alapján történtek az éves értékelések, kivéve az anyagi-pénzügyi feladatokat, e téren követték a naptári évet. 1968-tól megszünt a határőrizeti időszak szerinti rendszer. Helyette a naptári év szerinti értékelést és parancskiadást vezették be féléves, majd éves rendszerben. A határőrizeti parancs felépítése és tartalma lényegében nem változott, amennyiben azt a határörizeti-operatív helyzet megkívánta esetenként kiegészítő határörizeti parancsokat is kiadtak:

- A kiképzés megszervezésére úgynevezett „Kiképzési Parancs”-ok születtek. Az újonckiképzésre rendszerint külön készült parancs. Ugyancsak külön kerültek kiadásra a hivatásos és sorállomány oktatásával, nevelésével foglalkozó parancsok A kiképzési parancsok mellékleteiként adták ki a különböző kiképzési terveket. 1968-tól a lövészetekre külön „lövészeti parancs”-ok készültek.

- A személyi állománnyal kapcsolatos feladatokra (mozgatás, bevonulás, leszerelés, előléptetés, kitüntetés stb.) állományparancsok készültek külön a hivatásos és külön a sorállomány részére. Egyegy konkrét feladatra esetenként külön kerületparancsnoki parancsot adtak ki.

- A kerületparancsnokságok feladatai, valamint egyes kiemelt feladatok (miniszteri parancsok, utasítások) végrehajtására a kerület részére „Intézkedési Terv”-ek készültek. 1968-tól a kerületparancsnokságok részére munkaterv, naptári- és ellenőrzési terv készült.

- A kerületek szervezetei, (szolgálatok) előbb negyedéves, majd féléves rendszerben tervezték a munkájukat.

- A pénzügyi-anyagi szolgálatok — később főnökségek — a felhasználásra javasolt pénzügyi, anyagi javakról éves költségvetést és terveket terjesztettek fel a Határörség Országos Parancsnokságra.

- A kerületek ellenőrzését 1966-ig felügyeleti szemle, utána bizottsági és célellenőrzési rendszerben valósították meg. A kerületek az alegységeket bizottsági-, cél-, segítő- és utóellenőrzésekkel ellenőrizték. Az ellenőrzések tapasztalatait jegyzőkönyvben, jelentésben rögzítették.

A kerületek irányító tevékenységében, az irányítás okmányaiban 1968-tól jelentős változások történtek. Országos szinten egységesítették az okmányokat. Megkezdődött az ügyrendek, munkarendek kidolgozása. Egységes elvek alapján dolgozták ki a határőrizeti elhatározásokat.

Az 1968-as csehszlovákiai események katonai, határőrizeti tapasztalatainak felhasználásával kidolgozták a magasabb harckészültségi fokozatok okmányait, azokat begyakoroltatták. A harckészültségbe helyezési „M” tervek elöbb csak kerületi majd alegység szinten készültek el.

Jegyzetek:

${ }^{1}$ A határörség országos parancsnokának 1958. évi jelentése.

HI. országos parancsnoki iratok.

2 - A határőrség országos parancsnokának 1959. évi összefoglaló jelentése. 001/1983.BM HÖR OPK pcs. ; HI. Országos parancsnoki iratok. ; NAGY

${ }^{3}$ A BM Határörség 1971. évi munkájának az értékelése. HI. 0020/1971.

4 A BM Határörség 1972. évi munkájának az értékelése. HI. 0020/1972.

5 A BM Határőrség 1973. évi munkájának az értékelése. HI. 0020/1973.

${ }^{6}$ A BM Határörség 1974. évi munkájának az értékelése. HI. 0020/1974.

${ }^{7}$ A BM Határőrség 1975. évi munkájának az értékelése. HI. 0020/1975. 
${ }^{8}$ A BM Határőrség 1976. évi munkájának az értékelése.

HI. 0020/1976.

${ }^{9}$ A BM Határőrség 1977. évi munkájának az értékelése.

HI. 0020/1977.

${ }^{10}$ A Magyar Szocialista Munkáspárt Politikai Bizottságának 1965. V. 11-ei határozata az 50 km hosszúságú kísérleti jelzőrendszer telepítésére és e szakaszon az aknazár felszedésére.

PIL. MSZMP Pol.Biz. határozatai.

${ }^{11}$ A Magyar Szocialista Munkáspárt Politikai Bizottságának 1966. VI. 21-ei határozata az SZ-100-as jelzőrendszer telepítése és az aknazár felszedése a nyugati határ mentén.

PIL. MSZMP Pol.Biz. határozatai.

12 0017/1965.BM.ut. 0017/1965.BM.ut. az 50 és 500 méter széles határsáv megszüntetéséről.

HI. Belügyminisztériumi utasítások, parancsok, intézkedések.

${ }^{13}$ 2002/1969.FMPK. határozat a nyugati határszakasz megszüntetéséről.

HI. kormányhatározatok.

${ }^{14}$ A BM Határőrség 1978, 1979, 1980. évi munkájának értékelései.

HI. 0020/1978, 0020/1979, 0020/1980.

${ }^{15}$ 001/1981.HM-BM.pcs. a Magyar Népköztársaság légi határőrizetének biztosításáról.

HI. Belügyminisztériumi utasítások, parancsok, intézkedések.

${ }^{16}$ MSZMP. Pol.Biz. 1986. IX. 9-ei határozata a Központi Bizottságnak a BM munkájára vonatkozó 1969. XI. 28-ai határozatában foglaltak végrehajtásának teljesítéséről.

PIL. MSZMP Pol.Biz. határozatai.

${ }^{17}$ A BM Határörség 1981, 1982, 1983, 1984. évi munkájának értékelései.

HI. 0020/1981, 0020/1982, 0020/1983, 0020/1984.

${ }^{18}$ A minisztertanács 1989. V. 18-ai határozata az elektromos jelzőrendszer lebontásával, a hatósági korlátozások, a határsáv és a nyomsáv megszüntetéséröl.

HI. kormányhatározatok.

${ }^{19}$ A Magyar Népköztársaság kormányának 1989. IX. 11-ei határozata a kelet-német állampolgárok határátléptetéséről.

HI. kormányhatározatok.

${ }^{20}$ A BM Határőrség 1985, 1986, 1987, 1988. évi munkájának értékelései.

HI. 0020/1985, 0020/1985, 0020/1987, 0020/1988.

${ }^{21}$ MSZMP. Pol.Biz. 1987. V. 19-ei határozata a határforgalom ellenőrzésének gyorsításáról.

PIL. MSZMP Pol.Biz. határozatai.

${ }^{22}$ 001/1981.HM-BM.pcs. a Magyar Népköztársaság légi határőrizetének biztosításáról. op.cit.

${ }^{23}$ A minisztertanács 1989. V. 18-ai határozata az elektromos jelzőrendszer lebontásával, a hatósági korlátozások, a határsáv és a nyomsáv megszüntetéséről. op.cit.

Jegyzetekben alkalmazott röviditések:

\section{KÉZIRATOK}

NAGY

NAGY György: A határforgalom és a határforgalom ellenörzés története 1945-1980. Egyetemi doktori disszertáció (ZMKA) Kézirat. Budapest, 1987.

\section{LEVÉL-, IRAT- ÉS DOKUMENTUMTÁRAK}

HI

PIL
- Határörség Irattára.

- Politikatörténeti Intézet Levéltára

Határforgalom 1960-1990

\begin{tabular}{|c|c|c|c|c|}
\hline \multirow{2}{*}{ Év } & \multicolumn{2}{|c|}{ Személyforgalom } & \multicolumn{2}{|c|}{ 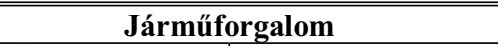 } \\
\hline & Összesen & $\begin{array}{c}\text { Növekedés \%-a } \\
\text { az elöző évhez } \\
\text { viszonyítva }\end{array}$ & Összesen & $\begin{array}{c}\text { Növekedés \%-a } \\
\text { az előző évhez } \\
\text { viszonyítva }\end{array}$ \\
\hline 1960 & 2399172 & - & 2853880 & - \\
\hline 1965 & 7115021 & $297 \%$ & 4521932 & $158 \%$ \\
\hline 1970 & 16001539 & $225 \%$ & 6158031 & $136 \%$ \\
\hline 1975 & 25922923 & $162 \%$ & 9247242 & $150 \%$ \\
\hline 1980 & 41615200 & $161 \%$ & 12350278 & $134 \%$ \\
\hline 1985 & 45205933 & $109 \%$ & 13579981 & $110 \%$ \\
\hline 1986 & 49968273 & $111 \%$ & 14682316 & $108 \%$ \\
\hline 1987 & 56304561 & $113 \%$ & 15889704 & $108 \%$ \\
\hline 1988 & 62814207 & $112 \%$ & 17952355 & $113 \%$ \\
\hline 1989 & 90857335 & $145 \%$ & 25466693 & $142 \%$ \\
\hline 1990 & 112026533 & $123 \%$ & 31328303 & $123 \%$ \\
\hline
\end{tabular}

Forrás ! Határőrségi Irattár országos parancsnoki iratok 1960-1990. 